\title{
SOME SOLUTIONS TO IMPROVE TRAINING QUALITY OF TOURISM HUMAN RESOURCES IN TRAINING AND EDUCATIONAL INSTITUTIONS IN THAI NGUYEN PROVINCE
}

\author{
Hoang Thi Kim Khanh", Bui Thi Thanh Van
}

Thai Nguyen College of Economics and Finance

\section{ABSTRACT}

The 4th Industrial Revolution has had a great impact on the sectors of economic, social and cultural life, including tourism. The 4th Industrial Revolution will contribute to the diversification of tourism products and increase the attractiveness of tourism. At the same time, it also gives out the requirements to localities in the tourism development strategy to become a key economic sector. In that context, Thai Nguyen province has also taken the initiative in making changes in the field of tourism and training of human resources to meet the demand of Industrial Revolution 4.0. Based on the results of the research on the human resources of tourism in Thai Nguyen, the authors assessed the advantages as well as the shortcomings that need to be overcome, thereby suggesting some solutions to improve the quality of training human resources in tourism, supplying the tourism market with dynamic, creative, professional, skilled and decent human resources and creating a decisive basis for the success of the tourism development target of Thai Nguyen province in particular and of Vietnam in general.

Keywords: Human resources; tourism; training; quality; industrial revolution 4.0

Received: 25/5/2019; Revised: 12/6/2019; Approved: 14/6/2019

\section{MỘT SỐ GIẢI PHÁP NÂNG CAO CHẤT LỰ̛̣NG ĐÀO TẠO NGUỒN NHÂN LỬC DU LỊCH TẠI CÁC CƠ SỞ GIÁO DỤC ĐẢO TẠO TRÊN ĐỊA BẢN TỈNH THÁI NGUYÊN TRONG THỜI ĐẠI 4.0}

Hoàng Thị Kim Khánh", Bùi Thị Thanh Vân Truờng Cao đẳng Kinh tế - Tài chính Thái Nguyên

\section{TÓM TĂT}

Cuộc cách mạng công nghiệp lần thứ 4 (CMCN 4.0) đã ảnh hưởng rất lớn đến các ngành, lĩnh vực của đời sống kinh tế, văn hóa xã hội, trong đó có lĩnh vực Du lịch. $\mathrm{CMCN} 4.0$ sẽ góp phần làm đa dạng hóa các sản phẩm du lịch, tăng thêm sức hấp dẫn của du lịch. Đồng thời, cũng đặt ra yêu cầu đối với các địa phương trong chiến lược phát triển du lịch trở thành ngành kinh tế mũi nhọn. Trong bối cảnh đó, tỉnh Thái Nguyên cũng đã chủ động có những thay đổi trong lĩnh vực du lịch và đào tạo nguồn nhân lực để đáp ứng nhu cầu của $\mathrm{CMCN} 4.0$.

Dựa trên kết quả nghiên cứu về thực trạng nguồn nhân lực du lịch tỉnh Thái Nguyên, nhóm tác giả đánh giá những ưu điểm cũng như những hạn chế cần khắc phục, từ đó đề xuất một số giải pháp góp phần nâng cao chất lượng đào tạo nguồn nhân lực, cung cấp cho thị trường nguồn nhân lực du lịch năng động, sang tạo, chuyên nghiệp, có tay nghề cao, tạo cơ sở quyết định cho sự thành công của mục tiêu phát triển ngành du lịch tỉnh Thái Nguyên nói riêng, và của Việt Nam nói chung.

Từ khóa: Nguồn nhân lục; du lịch; đào tạo; chất luợng; cách mạng công nghiẹp 4.0

Ngày nhận bài: 25/5/2019; Ngày hoàn thiện: 12/6/2019; Ngày duyệt đăng: 14/6/2019

* Corresponding author: Email: khanhcdkt@gmail.com

DOI: https://doi.org/10.34238/tnu-jst.2019.06.1594 


\section{Introduction}

The 4th Industrial Revolution is growing rapidly in the world and directly affecting Vietnam. This revolution creates an environment in which computers, automation, and people work together in totally new ways. The 4th Industrial Revolution gives us many opportunities but also countless challenges. Such opportunities and challenges are posed to not only one or several sectors but also all sectors, including tourism. The 4th Industrial Revolution helps the tourism industry create more attractive new tourism products, stimulate growth and develop sustainable tourism. Industrial application 4.0 will reduce the cost of time, labor, production costs, and reduce the cost of tourism services. To adapt to the industrial revolution, it is required that the human resources in the tourism industry must ensure skills, professional qualification and proficient use of intelligent tourism management software and technology.It means that the training institutions of human resources in tourism must also have drastic changes in the training curriculum and application of new technologies and combine training with businesses and society.

Tourism is one of the economic sectors being prioritized by the Party and the State to become a key economic sector of the country. Thai Nguyen is a province with many potentials for tourism development with its strengths in ecotourism and tourism in historical landmarks. At present, Thai Nguyen province has 810 historical and cultural relics and scenic spots listed and protected according to the provisions of the Cultural Heritage Law, including 510 historical monuments, 39 scenic monuments, 12 archeological relics, 16 architectural art monuments and 233 religious relics. Typical examples are the National Relics of DinhHoa Safety Zone; Than $\mathrm{Sa}$ archaeological relic (Vo Nhai); Duom Temple (Phu Luong); Hang Pagoda (Dong Hy)... There are many destinations which bring visitors interesting experiences and are close to the nature. Visitors can go on a boat trip to visit large and small islands on Nui Coc Lake (Dai Tu), climb the mountain in Vo Nhai to conquer Phuong Hoang cave, swim in cool fresh water in Mo Ga stream; or go to Pho Yen to swim on Suoi Lanh lake, watch corn fields and tea fields. All of them create a beautiful picture of Thai Nguyen tourism [1].

With the proper attention of the leaders of the province and the state, that potential has become more and more advantageous, bringing Thai Nguyen tourism with remarkable achievements reflected in the increasing number of domestic and foreign tourists coming to Thai Nguyen. In order to further promote the advantages of tourism and fulfill the goal of making tourism an important economic sector, especially in the context of the industrial revolution 4.0, one factor to be considered is that workforce in tourism and quality of training human resources in tourism in Thai Nguyen province. Human resources as well as the training of human resources in tourism play an important role in contributing to the achievements of the tourism. At the same time, they were also affected by the impacts of the industrial revolution 4.0 in terms of both advantages and difficulties. In fact, human resources and the training of human resources in tourism in Thai Nguyen province have many advantages but there are also limitations that need to have appropriate solutions to improve the training quality of human resources, provide the market with a dynamic, creative, professional, highly skilled tourism human resource, create a decisive basis for the success of the tourism development goal in Thai Nguyen province in particular and in Vietnam in general.

\section{Content}

\subsection{The role of training human resources in tourism in tourism development in Thai Nguyen province}

Human resources for tourism are the subjects participating in the process of tourism and socio-economic development. The tourism workforce is responsible for forecasting, 
creating, leading and guiding the community to become creative forces of new tourism values, not only the objects of exploitation and enjoyment. These resources must be a force not to help and guide people to understand and apply science and technology in working; keep abreast of practical life, actively participate in hunger eradication and poverty reduction, job creation, intellectual and physical improvement for the people but to in rich people, and gain a fair and civilized society. In addition, tourism human resources play a pioneering role in the creation of tourism values of the international labor division in the context of increasingly deep and comprehensive international integration. With such a role, improving the quality of training tourism staff is an urgent requirement.

As a midland province in the northern mountainous region, Thai Nguyen has favorable natural conditions for tourism development with many typical landscapes of Viet Bac region, many revolutionary historical relics, physical and intangible cultural values of ethnic minorities in the area. With that potential, Thai Nguyen tourism is growing steadily. In 2018, Thai Nguyen maintained a stable growth rate of tourism to ensure its objectives. The total number of tourists to Thai Nguyen is $2,506,481$, an increase of $12.4 \%$ compared with the same period last year, of which the number of international tourists is 70,297 , an increase of $6 \%$ compared with the same period last year, and tourists served in tourism accommodation facilities reach 1,023 .435, an increase of $8 \%$ compared with the same period; the number of tourists to the tourist attractions is $1,347,986$, increased by $16 \%$ compared with the same period; the number of visitors that tour companies served is 135,060 , increased by $22 \%$ compared with the same period. Total revenue from tourism enterprises reached 405 billion VND [2]. To gain that achievement, there is a significant contribution of the tourism workforce. The potential of Thai Nguyen tourism is undeniable, but without the contribution of human resources in tourism, that potential will not be able to promote and bring achievements to the province. This is the team that plays the driving force of the tourism development process and is considered a valuable asset, directly impacting the competitiveness, business efficiency of the business as well as the sustainable development of the tourism. The higher the quality of human resources is, the more tourism will develop.

Therefore, to develop tourism, the first thing to do is to develop human resources in both quantity and quality. The requirement to develop human resources in tourism is more urgent than ever when the State now advocates to develop tourism to become a key economic sector in Resolution 08-NQ/TW dated January 16, 2017 of the Politburo [3]. At the conference of reporting specific tasks of developing tourism to become an important economic sector which creates a driving force for socio-economic development, Mr. Tran Quoc To, Member of the Party Central Executive Committee, the Provincial Party secretary of Thai Nguyen province also emphasized "Building key tourist destinations and routes to attract domestic and international tourists, concentrating on developing tourism to become an important economic sector". Thai Nguyen is determined to promote tourism development, which means promoting the quality of human resources in tourism. Whether or not human resources in tourism is abundant, professional, capable and creative depends on training. Only staff with skills, experience, ability, and creativity can meet the requirements of the times. That capacity must be based on basic education - training. That is an opportunity, also a big challenge for training institutions, from vocational training 
schools to colleges and universities across the country in general and Thai Nguyen province in particular. Through training programs at educational institutions, learners will be able to improve their professional knowledge and skills so that they can fulfill their tasks at different positions in travel businesses, hotels, restaurants, management agencies on tourism... and thereby forming a staff of tourism of high quality meeting practical needs.

Thus, training human resources plays a very important role in the tourism development strategy of Thai Nguyen province. In order to achieve the goal of developing tourism into an important economic sector, Thai Nguyen needs to focus on improving the quality of human resource training in its own human resource training institutions.

\subsection{The effect of the industrial revolution 4.0 to the training human resources in tourism in Thai Nguyen province}

The industrial revolution 4.0 is the revolution of smart production based on groundbreaking achievements in the areas of artificial intelligence, virtual reality, mobile network, Internet of Things, cloud computing, automatic machine... with the foundation of breakthroughs in digital technology. Currently, The industrial revolution 4.0 is in the inception phase and will affect all socio-economic areas, opening up many development opportunities because it is not only directed at industry and digital technology but it also brings outstanding achievements of digital technology to all areas including tourism and training of human resources in tourism in Thai Nguyen province.

New technologies will make travel services more responsive and flexible, information and data are constantly and widely updated. The industrial revolution 4.0 will contribute to increasing the ability of cooperation in developing tourism products, diversifying tourism products, increasing the attractiveness of tourism and increasing connectivity between countries. The industrial revolution 4.0 also requires enterprises to invest strongly and apply advanced tourism technology, especially information technology and telecommunications in online tourism business activities, strongly participate in global value chain in tourism. Thai Nguyen province has also actively made changes in the tourism sector to meet the needs of the industrial revolution 4.0. In 2018, VNPT of Thai Nguyen was in collaboration with the Department of Culture, Sports and Tourism of Thai Nguyen province to organize a conference to introduce and sign the Agreement on Cooperation to implement "Smart Tourism in Thai Nguyen Province". This is a component in Smart City, using information and communication technology to form a tourism ecosystem and create mutual benefits and serve 3 objects that are tourists, authorities and businesses. That is the solution to create an effective and sustainable development for Thai Nguyen tourism according to the development trend of technology 4.0. The industrial revolution 4.0 has changed the tourism and will certainly affect human resources, requiring human resources in the tourism to actively improve foreign languages, skills and spiritual skills associated with specific working groups and different social interests. In order for human resources to meet new requirements, the training of human resources in tourism also needs to be changed accordingly. The industrial revolution 4.0 requires the training of tourism human resources in Thai Nguyen province in particular and the country in general must renew the training program, curriculum, increase the amount of practice in enterprises; improve and update professional qualifications and technology for teachers; apply new technology in teaching theory and practice; strengthen training for students with soft skills, new technology application skills, communication skills and foreign language 
use in business activities; linking schools with businesses, training according to the needs of businesses and society.

The industrial revolution 4.0 has brought Thai Nguyen tourism many opportunities but also many challenges. To meet the requirements of the innovation in the technological age, human resources in tourism also need to be deeply and comprehensively innovated. Therefore, the training of tourism human resources cannot stand still, training must be associated with social needs, and technology application must be based on a practical basis and extensive cooperation. Thus, this forms a team of tourism manpower to operate the smart tourism effectively.

\subsection{Current situation of training human resources in tourism in Thai Nguyen province in the context of the industrial revolution 4.0}

Thai Nguyen has many potentials to develop tourism into a key economic sector, because in addition to the beautiful natural landscape, there are also tourist spots bearing its own cultural identity, including intangible cultural heritage which are preserved and respected. Like the tourism activities of the whole country, Thai Nguyen tourism is facing the opportunities and challenges set by the industrial revolution 4.0. Over the years, Thai Nguyen has achieved many achievements in the field of tourism.

Obviously, in order to have a tourism workforce contributing positively to the overall achievements of the tourism, the training of human resources is an indispensable factor, including training at educational institutions and retraining work of management agencies and enterprises. This is also an advantage of Thai Nguyen province because it is considered as the 3rd largest human resource training center of the country with 9 universities, 11 colleges and many vocational schools. Currently, the province has 04 establishments participating in training human resources in tourism: University of Economics and Business Administration, University of Science, Thai Nguyen College of Economics and Finance, Thai Nguyen College of Trade and Tourism. Universities and colleges have implemented many reforms in the training program to meet the requirements in the context of the industrial revolution 4.0 to train human resources of high quality for the province as well as for the whole country. According to the official dispatch No. 4929/ BGDĐT-GDĐH dated October 20, 2017 of the Ministry of Education and Training on the application of a special mechanism for different training areas in tourism, the universities and colleges have also implemented the projects applying a special mechanism for different training areas in tourism industry. On that basis, they will collaborate with businesses and tourism associations to forecast labor demand, connect recruitment, build output standards and coordinate in student training. The training program is built in the direction of open and inter-connected application including core modules and elective modules. Foreign language and soft skill training is improved to enhance job opportunities for students. Actual training time at the enterprise must ensure $50 \%$ of the total training time and be specified in the training program. Universities and colleges are also promoting comprehensive cooperation with tourism associations, reputable companies and businesses in Thai Nguyen province such as: DONG A Hotel Group, Da Huong Hotel, Hoang Mam restaurant - hotel, Sao Viet Events and Tourism Limited company, Au Lac International Tourism Joint Stock Company... to use the facilities, equipment and software of the enterprise to practice to improve practical skills and practical application of students. 
Table 1. Results of tourism activities in Thai Nguyen province in two years of 2017 and 2018

\begin{tabular}{cccccc}
\hline \multirow{2}{*}{ TT } & Target & $\mathbf{2 0 1 7}$ & $\mathbf{2 0 1 8}$ & $\begin{array}{c}\text { Absolute } \\
\text { number }\end{array}$ & Relative number \\
\hline 1 & Total numbers of tourists & $2,229,700$ & $2,506,481$ & 276,781 & $12.4 \%$ \\
\hline 2 & Number of interntional tourists & 66,297 & 70,297 & 4,000 & $6 \%$ \\
\hline 3 & $\begin{array}{l}\text { Total revenue of tourism } \\
\text { businesses (billion VND) }\end{array}$ & 310 & 405 & 95 & $30.6 \%$ \\
\hline
\end{tabular}

Source: Thai Nguyen Department of Culture, Sports and Tourism [2]

In addition, Thai Nguyen tourism staff is also interested in by the Association and management agencies. Every year, Thai Nguyen Tourism Association has cooperated with functional agencies to organize training and retraining courses of professional for the workforce in the field of tourism, basically on hotel reception, room service and tour guide.

In addition to the efforts of training institutions for human resources in tourism of Thai Nguyen province to best meet the demand for human resources in tourism in the context of the industrial revolution 4.0, the training still has some shortcomings. Most training institutions have been aware of and determined in the right direction to change the training program to meet new requirements, but at the present time the universities and colleges are mainly implementing but not completed, which leads to certain limitations:

- In terms of the training program: Training institutions in Thai Nguyen province in the past years have actively changed the training program towards reducing academic theory, increasing practice but in fact students' practice time in businesses is still too little and students lack practical access opportunities so after graduation, they lack the necessary skills to work.

- Training methods: Training institutions have constantly innovated methods, applied active teaching methods. However, the quality of students' input, especially the college and university students' input is very low, students are not able to recognize and interact with teachers while the core of active teaching is increasing the interaction between lecturers and students to stimulate students' initiative and creativity. Therefore, the improvement of the training method has not been fully utilized. Even in many cases, lecturers must go back to implement traditional training methods, providing oneway information to suit students.

- Quality of teaching staff: Most of the teaching staff at the training institutions were graduated from the universities of culture, society, business administration... therefore, the in-depth knowledge of tourism is not much, the level of foreign language and information technology is not high enough to apply the advancement of information technology to teaching. In addition, the lecturers are mainly those who are accepted to teach right after graduation, so students' actual knowledge in tourism businesses is not good enough. This also makes the lecture not really lively, attractive and unrealistic.

\subsection{Solutions to improve the quality of training human resources in tourism in Thai Nguyen province in the context of industrial revolution 4.0}

The training of human resources in tourism in Thai Nguyen province as well as across the country has made positive changes but there are also certain shortcomings. In order to timely meet the demand of the workforce in the tourism industry in the context of the industrial revolution 4.0, Thai Nguyen province needs to implement a number of measures to improve the quality of training human resources in tourism: 
- In terms of the training program:

+ Improve the curriculum of international standards, in line with the VTOS standard framework and the curriculum meets the requirements of the society.

+ Frequently consult with employers, even tourists, to design training programs suitable with reality.

- In terms of training methods:

+ Increase the amount of practical time, improve students' self-study ability.

+ Strengthening collaboration with tourism businesses to create practical location for both students and lecturers.

+ Improve the foreign language quality of students. Every student after graduation must have the certificate of International English (IELTS, Toefl...). Encourage students to learn a second foreign language (Chinese, Korean, Japanese...)

+ Regularly organize seminars, seminars with leading experts in the field of tourism to help students to understand clearly and update new knowledge about the tourism industry.

+ Expanding and enhancing the activities of clubs such as the reception club, tour guide club, presentation club... to increase the cohesion and dynamism of students.

+ Improving the input quality of students of tourism, based on the following criteria: Appearance, Foreign Language, Communication and Conduct ability, ability to handle situations...

- In terms of the quality of teaching staff:

+ Training institutions need to regulate the required number of hours working in tourism enterprises.in the academic year of lecturers.

+ Strengthening international cooperation, organizing long-term and short-term training courses for lecturers to learn in developed countries.

\section{Conclusion}

The 4th industrial revolution has influenced greatly on the sectors and fields of economic, cultural and social life, including tourism. This revolution will contribute to diversify tourism products and increase the attractiveness of tourism. At the same time, this also sets up requirements for localities in the strategy of tourism development to become a key economic sector. In this context, Thai Nguyen province has actively taken changes in tourism and human resources training to meet the needs of this revolution. Through the research results on the status of tourism human resources in Thai Nguyen province, it can be seen that the training of tourism human resources in educational and training institutions still has some problems about the training program, training methods as well as the teaching staff quality. Writers propose a number of solutions to complete the training program, innovate training methods, improve teaching staff quality in order to improve the quality of training human resources for tourism, provide the market dynamic, creative, professional and highly skilled tourism human resources, which creates a decisive basis for the success of the tourism industry development goal in Thai Nguyen province particularly and in which Vietnam generally.

\section{REFERENCES}

[1]. Pham Chuan, Bich Ngoc, "Tourism through Viet Bac heritage areas", 11/15/2017, http://www.baobackan.org.vn/channel/12413/ 201711/thai-nguyen-phat-trien-du-lich-tro thanh-nganh-kinh-mui-nhon-5558458, access time 04/15/2019.

[2]. Thai Nguyen Department of Culture, Sports and Tourism, Summary report of cultural, sports and tourism activities in 2018, the tasks of the year 2019, 2019.

[3]. Politburo, Resolution $08-N Q / T W$ dated January 16, 2017 of the Politburo on developing tourism to become a key economic sector, 2017. 
[4]. Central Executive Committee, Resolution No. 05-NQ / TW dated November 1, 2016 on a number of major undertakings and policies to continue to renovate the growth model, improve the quality of growth, productivity, competitiveness of the economy, 2016.

[5].Government, Decree No. 101/2017 / ND-CP dated September 1, 2017 on training and retraining of cadres, civil servants and officials, 2017.

[6]. Duc Hieu, Industrial Revolution 4.0 will change the tourism industry drastically, 6/19/2017, $\quad$ https://dulich.tuoitre.vn/du- lich/cach-mang-40-se-thay-doi-manh-nganhdu -lich-1334136.htm, access time 04/15/2019.

[7]. Minh Khoa, What is the Fourth Industrial Revolution?,07/27/2017,

https://baomoi.com/cuoc-cach-mang-congnghiep-4-0-la-gi/c/22861841.epi, access time 04/15/2019.

[8]. Minh Hoang, Tourism industry with industrial revolution 4.0, 6/19/2017 http://toquoc.vn/Thoi_su/nganh-du-lich-voicach-mang-cong-nghiep-40-243427.html, access time 04/15/2019. 